\title{
Enteral Absorption of Erythropoietin in the Suckling Rat
}

\author{
AMY L. MILLER-GILBERT, SUZANNE H. DUBUQUE, BOHUSLAV DVORAK, \\ CATHERINE S. WILLIAMS, JAMES G. GRILLE, SUANN S. WOODWARD, \\ OTAKAR KOLDOVSKY $\uparrow$, AND PAMELA J. KLING
}

Departments of Pediatrics (A.L.M.-G., S.H.D., B.D., C.S.W., J.G.G., S.W., O.K., P.J.K.) and Physiology (O.K.), The University of Arizona Health Sciences Center, Steele Memorial Children's Research Center, Tucson, Arizona 85724-5073, U.S.A.

\begin{abstract}
Milk contains biologically relevant concentrations of erythropoietin (Epo), the primary hormone responsible for erythrocyte production. In animals, milk-borne Epo stimulates erythropoiesis. Epo receptors have been found in nonerythropoietic tissues including gastrointestinal tract. We hypothesized that milk-borne Epo is distributed to local gastrointestinal tissues, absorbed intact, and then distributed peripherally via the systemic circulation. Rat milk protected recombinant human Epo (rhEpo) from degradation in the suckling rat gastrointestinal tract. Simulated digestion of ${ }^{125} \mathrm{I}$-rhEpo in suckling rat gastrointestinal juices was performed. When measured by acid precipitation and immunoassay, rat milk protected rhEpo from gastrointestinal juices better than saline $(p<0.0001)$. The fate of enterally administered milk-borne ${ }^{125} \mathrm{I}$-rhEpo was examined in 10 -d-old rats. RhEpo fed in rat milk was better protected from in vivo proteolytic degradation than rhEpo in saline $(p<0.05)$. After enteral ${ }^{125}$ I-rhEpo dosing, radiolabeled protein from gastric tissue comigrated on SDS-PAGE with intact rhEpo at $36.5 \mathrm{kD}$. To determine the local and systemic distribution of physiologic intakes of rhEpo, suck-
\end{abstract}

\section{ABSTRACT}

ling rats were fed ${ }^{125} \mathrm{I}$-rhEpo in rat milk, and tissues were harvested 1, 2, and $4 \mathrm{~h}$ later. Intact ${ }^{125} \mathrm{I}$-rhEpo was found in gastric and small intestinal walls and lumens. Five percent of total administered dose was found intact in the plasma, whereas another 8 to $10 \%$ of total administered dose was localized to bone marrow, percentages comparable to those seen after parenteral administration. Radiolabel was also localized to liver and peripheral solid tissues. These patterns of localization and degradation of rhEpo after acute administration support both systemic absorption and gastrointestinal cellular processing. (Pediatr Res 50: 261-267, 2001)

Epbo, erythropoietin
rhEpo, recombinant human erythropoietin
EpoR, erythropoietin receptor
RMS, rat milk substitute
TCA, trichloroacetic acid

Epo, the primary hormone regulating erythropoiesis, is produced in response to hypoxia or anemia. In addition to its erythropoietic effects, Epo binds to its receptor (EpoR) and exerts mitogenic, vasodilatory, and angiogenic effects in a diverse group of nonerythropoietic tissues including gastrointestinal tract (1-4). Like many other cytokines and hematopoietic growth factors, biologically relevant levels of Epo are present in human milk (5).

In the neonate, immature gastrointestinal proteolysis, combined with the intrinsic proteolytic inhibition of milk and

\section{$\dagger$ Deceased.}

Received June 22, 2000; accepted February 12, 2001

Correspondence: Pamela J. Kling, M.D., Department of Pediatrics, PO Box 245073, University of Arizona, Tucson, AZ 85724-5073, U.S.A.; e-mail: pkling@peds.arizona.edu

Supported in part by the Arizona Disease Control Research Commission 1-272 (P.J.K.), Arizona and Southwest Affiliates of American Heart Association AZGS-37-96 and SW-GS-16-98 (P.J.K.), The University of Arizona Undergraduate Honors Research Grant (A.L.M.-G.), The University of Arizona Undergraduate Biology Research Program (A.L.M.-G.), and Program Project NIH HD 26013 (O.K., B.D., P.J.K.). greater intestinal mucosal permeability, allows undigested milk-borne proteins to be absorbed and delivered to distant sites via blood (6-8). In vitro digestion studies with human neonatal gastric juices have shown that Epo in saline is partially degraded, but the presence of human milk inhibits proteolytic degradation of Epo (5).

Previously published work has evaluated erythropoiesis after enteral Epo administration. In adult rats, enterally administered rhEpo exhibits no erythropoietic effects except when given rectally in the presence of salicylates that improve rectal mucosal permeability (9). Erythropoiesis was stimulated in suckling rats after maternal hypoxia or anemia or after enteral supplementation of cow's milk with Epo (10-12). In human premature infants, two preliminary studies support that enteral rhEpo is absorbed $(13,14)$. Both Britton et al. (13) and Ballin et al. (14) showed higher plasma Epo levels after enteral rhEpo administration, and Ballin, et al. observed reticulocytosis and lower plasma ferritin levels with enteral rhEpo treatment (14). 
To date, no studies have examined the nonerythropoietic effects of enterally administered rhEpo despite several lines of investigation indicating that Epo plays a role in gastrointestinal biology. For example, in vitro studies suggested that rhEpo caused proliferation of gastric and intestinal mucosa after receptor binding $(3,4)$. Recently, a clinical study has shown that parenteral rhEpo therapy is associated with a lower incidence of necrotizing enterocolitis (15). To begin to address the potential nonerythropoietic roles of enteral rhEpo, we first needed to assess the level of absorption and distribution of enterally administered rhEpo. We selected the rat model because of its utility in investigating neonatal erythropoiesis (11, 16) and gastrointestinal tract development (17) and because rhEpo has been shown to have biologic activity in rats (18). We set out to test the hypothesis that milk-borne Epo is distributed throughout the gastrointestinal tract, absorbed into systemic circulation, and delivered to hematopoietic tissues.

\section{METHODS}

\section{Experimental Design}

Animals. The present study was approved by the Institutional Animal Care and Use Committee. Sprague-Dawley rats were bred and delivered in-house, with litters reduced to 10 pups on the second postnatal day to standardize litter size. Rat milk was manually expressed from dams after $10 \mu \mathrm{g} / \mathrm{kg}$ fentanyl anesthesia and $2 \mathrm{U}$ oxytocin after removal of her litter for $5 \mathrm{~h}$ (19) and was stored at $-70^{\circ} \mathrm{C}$ until use. RMS formula was prepared (20) and studied fresh within $4 \mathrm{~d}$. On the day of study, suckling rats were weighed after removal from their mothers, sex was determined by examination, and they were fasted on a $33^{\circ} \mathrm{C}$ heating pad to maintain normal body temperature. Before sampling and death, the rats were given inhaled ether or a ketamine and xylazine mixture (1:1) s.c.

In vitro digestion assay. For collection of gastric and proximal small intestinal juices, 10-d-old rats were fasted for $2 \mathrm{~h}$, fed Pedialyte via gastric tube, and fasted for an additional $2 \mathrm{~h}$ before anesthesia and death. Gastric and proximal small intestinal luminal contents were harvested by flushing with $1 \mathrm{~mL}$ of saline and stored at $-70^{\circ} \mathrm{C}$. To approximate neonatal gastrointestinal physiology, three incubation buffers were used: 1 ) $0.1 \mathrm{M}$ glycine, $\mathrm{pH} 3.2$, to simulate preprandial gastric conditions; 2) $0.1 \mathrm{M}$ maleate, $\mathrm{pH} 5.8$, to simulate postprandial gastric conditions; and 3) $0.01 \mathrm{M}$ Tris, $6.7 \mathrm{mM} \mathrm{CaCl}_{2}, \mathrm{pH} 7.4$, to simulate proximal small intestine $(5,21)$.

Equivalent volumes of buffer, aqueous fraction of neonatal gastric juice, and substrate were incubated at $37^{\circ} \mathrm{C}$ for $15 \mathrm{~min}$ (baseline degradation) and $2 \mathrm{~h}$ to span the normal stomach and small intestine transit time $(5,22)$. Substrates included 1$)$ saline, 2) RMS artificial formula, and 3) aqueous fraction of rat milk. Substrates were supplemented with $10,000 \mathrm{cpm}{ }^{125} \mathrm{I}-$ rhEpo (Amersham) in $150 \mathrm{mU} / \mathrm{mL}$ rhEpo (Amgen) to evaluate degradation via TCA precipitation (5) or $150 \mathrm{mU} / \mathrm{mL}$ of unlabeled rhEpo to evaluate degradation via RIA (Diagnostic Systems Laboratories, Inc., Webster, TX, U.S.A.). We selected ${ }^{125} \mathrm{I}$-rhEpo with lower specific activity $(300-900 \mu \mathrm{Ci} / \mathrm{mM})$ as previous studies showed it displayed greater biologic stability and normal receptor binding (23). Gastric juice samples $(n=$
5 ) were incubated at pre- and postprandial $\mathrm{pH}$ with all three substrates, and proximal small intestinal juices $(n=5)$ were incubated at $\mathrm{pH} 7.4$ with all three substrates. Reactions were stopped with addition of $1 \mathrm{M}$ Tris, $\mathrm{pH}$ 8. Radioactivity for both TCA and RIA assays was detected with a Cobra AutoGamma Counter (Packard Instruments, Meriden, CT, U.S.A.). TCA was used to precipitate large proteins, leaving digested products in the supernatant. BSA was used as a carrier protein to ensure good separation of the TCA pellet $(5,24)$. Cold TCA in BSA was added to the reaction mixtures to a final concentration of $12 \%$ TCA, $2 \%$ BSA. Reaction mixtures were centrifuged at $16,000 \times g$ for $20 \mathrm{~min}$ at $4^{\circ} \mathrm{C}$, supernatants were decanted from pellets, and both were counted separately to determine percent intact radiolabeled proteins.

Enteral ${ }^{125}$ I-rhEpo studies. Suckling rats were fasted for $5 \mathrm{~h}$, then fed $75,000-100,000 \mathrm{cpm}{ }^{125} \mathrm{I}$-rhEpo in $400 \mathrm{mU}$ rhEpo delivered in $200 \mu \mathrm{L}$ of rat milk. The rat milk aliquots had assayable Epo, but the added rhEpo dose was 50-100 times endogenous levels, which should not alter rhEpo disposition patterns. The rhEpo dosing was not pharmacologic; rather, it was twice the estimated physiologic daily intake to evaluate normal physiologic distribution. To ensure stability and equal distribution, mixtures were kept at $4^{\circ} \mathrm{C}$, then vortexed and warmed before administration. Feeds were bolused via an orogastric tube $(3.5 \mathrm{~F}$ umbilical catheter, Sherwood Medical) advanced to $5 \mathrm{~cm}$. Death occurred immediately $(0 \mathrm{~h})$, 1,2 , or $4 \mathrm{~h}$ after ${ }^{125}$ I-rhEpo administration. The immediate $(0$ h) sampling time represented dosing baseline, 1-h sampling represented maximal gastric proteolytic activity (25), 2-h sampling represented stomach emptying (22), and 4-h sampling was chosen to evaluate rhEpo distribution after gastric emptying. Each time interval included at least 10 animals obtained from three litters. A comparison group of parenterally (s.c.) dosed rats was studied $2 \mathrm{~h}$ after injection with 75,000-100,000 $\mathrm{cpm}^{125} \mathrm{I}$-rhEpo in $400 \mathrm{mU}$ of rhEpo mixed in $200 \mu \mathrm{L}$ of $2.5 \%$ BSA in saline in the dorsal neck area.

Tissue collection. After anesthesia, cardiac puncture was performed, whole blood microhematocrit was determined, and remaining blood was placed into Becton Dickinson EDTA Microtainers (Franklin Lakes, NJ, U.S.A.). After counting, whole blood tubes were centrifuged at $1000 \times g$ for $1 \mathrm{~min}$, and plasma was removed. After cardiac puncture, the animals were decapitated and tissues harvested as described by Philipps et al. (7). Briefly, the stomach, small intestine, and colon were removed, and the small intestine was divided into duodenum, jejunum, midjejunum, and ileum (7). The gastrointestinal segments were flushed with $2 \mathrm{~mL}$ of ice-cold $1 \mathrm{M}$ Tris buffer, $\mathrm{pH}$ 8.0, containing protease inhibitors (26). The liver, spleen, brain, and kidneys were removed. Each tissue/luminal flush was placed in preweighed $12 \times 75$ polypropylene tubes and weighed and frozen at $-70^{\circ} \mathrm{C}$. All specimens collected underwent TCA precipitation as described above. Before TCA precipitation, tissue and luminal flushes were homogenized for 30 s each by use of a Polytron homogenizer (Brinkman Instruments, Westbury, NY, U.S.A.). TCA and BSA were added to the tissues and flushes as described above.

SDS-PAGE. Molecular size of label from gastric tissue and luminal contents was determined by SDS-PAGE. The protein 
fraction of tissue and lumen homogenates was extracted following the manufacturer's instructions for Tri-Pure isolation reagent (Boehringer Mannheim, Indianapolis, IN, U.S.A.). A $4 \%$ polyacrylamide stacking and $15 \%$ polyacrylamide running gel was poured into a Bio-Rad Mini Protean II gel apparatus (Bio-Rad, Hercules, CA, U.S.A.). Samples containing 500$1000 \mathrm{cpm}$ were loaded into each well and run for $1 \mathrm{~h}$ at $140 \mathrm{~V}$ along with prestained standards. Gels were placed into plastic sleeves, exposed on X-omat AR film (Kodak, Rochester, NY, U.S.A.) at $-70^{\circ} \mathrm{C}$ for $2 \mathrm{wk}$, and developed. The $\mathrm{x}$-ray film was scanned and imaged with a Umax Vista-S6 scanner (Fremont, CA, U.S.A.) and Adobe Photoshop (Mountain View, CA, U.S.A.).

Bone harvest. The distribution of ${ }^{125} \mathrm{I}$-rhEpo cpm in bone at 1,2 , and $4 \mathrm{~h}$ after enteral feeding and $2 \mathrm{~h}$ after parenteral administration was determined. Bones were stripped of soft tissues, separated at joints, weighed, and placed in the gamma counter. Total counts of each bone group were compared with its weight. Because TCA precipitation could not be performed on the whole bone specimens, marrow biopsies from long bones were harvested from an additional group of rats at 1,2 , and $4 \mathrm{~h}$ after enteral feeding and $2 \mathrm{~h}$ after parenteral administration for TCA determination of intact and total ${ }^{125} \mathrm{I}$-rhEpo counts.

Data analysis. Simulated digestion TCA precipitation data and intact Epo levels are expressed as percent of the total ${ }^{125}$ I-rhEpo \pm SEM. RIA Epo levels and controls were calculated with polynomial regression (Statview 4.01) according to manufacturer's instructions. Enteral rhEpo studies are expressed as percent of the dose administered in total and acidprecipitable cpm \pm SEM. In enteral rhEpo studies, the dose administered was calculated by administering separate aliquots of the $200-\mu \mathrm{L}$ feeding volume into tubes and counting and then was confirmed by tallying all tissue cpm from the baseline ( 0 h) samples. The total counts of a blood aliquot were used to calculate the counts of the total blood volume, assuming that blood comprises $7 \%$ of body weight. Data were analyzed by 2-tailed paired or unpaired $t$ tests or 1-way ANOVA for multiple comparisons with Fisher's post hoc testing. An alpha level $<0.05$ was considered significant.

\section{RESULTS}

We evaluated the capacity of rat milk and artificial RMS to protect rhEpo from proteolytic degradation after in vitro exposure to suckling rat gastric juices at $\mathrm{pH} 3.2$ and 5.8 and intestinal juices at $\mathrm{pH} 7.4$ (Fig. 1, $A$ and $B$ ). By use of TCA precipitation to estimate intact rhEpo, at $2 \mathrm{~h}$ of incubation in gastric juices at pre- and postprandial stomach $\mathrm{pH}$, we found that ${ }^{125} \mathrm{I}$-rhEpo levels were higher in milk or RMS than in saline $\left(F_{2,12}=122.6, p<0.0001, F_{2,12}=14.3, p<0.001\right.$, respectively, with post hoc $p<0.05$ ). Similarly, ${ }^{125}$ I-rhEpo levels in small intestinal juices were higher in milk or RMS than in saline $\left(F_{2,12}=14.6, p<0.001\right.$, with post hoc $p<$ $0.05)$. In small intestinal juices, ${ }^{125}$ I-rhEpo levels in milk were higher than RMS (with post hoc $p<0.05$ ). With RIA, we measured rhEpo after simulated digestion for $2 \mathrm{~h}$ and found that after $2 \mathrm{~h}$, immunoreactive rhEpo levels were higher in milk

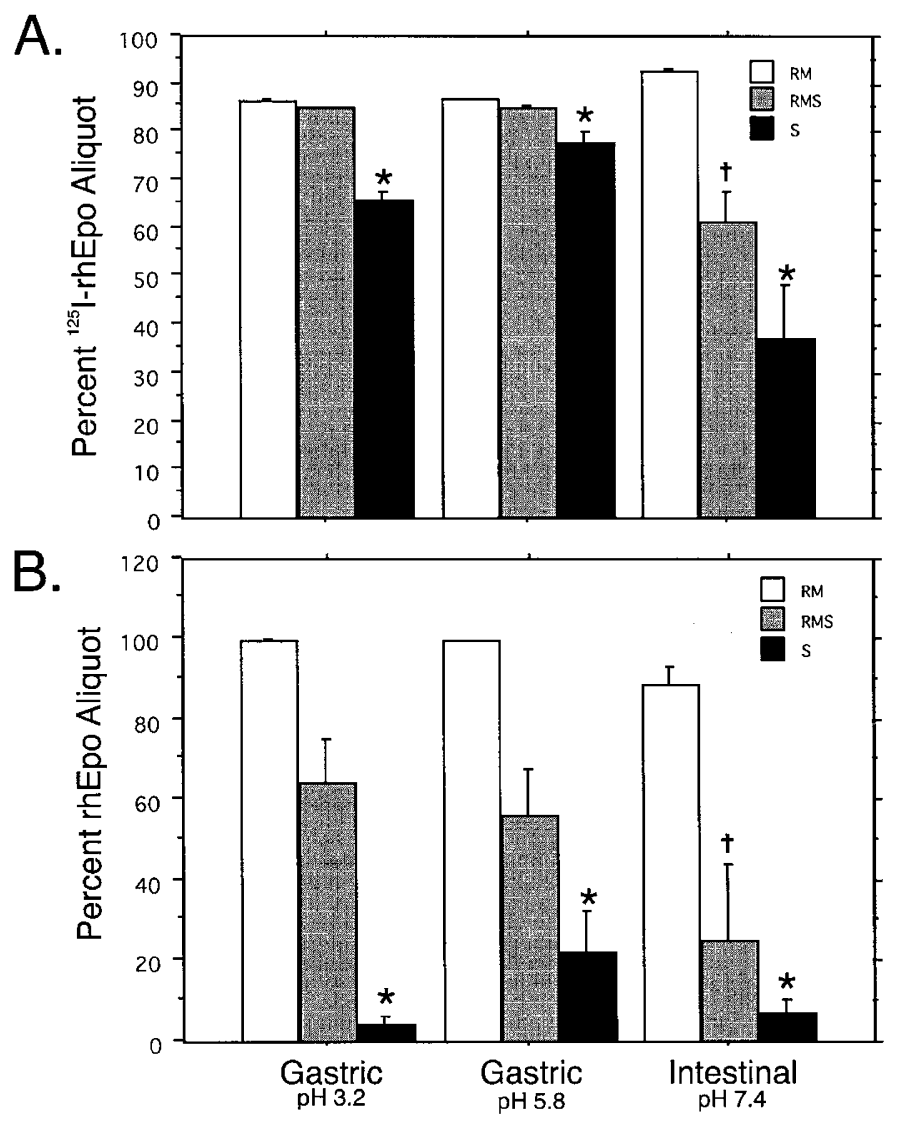

Figure 1. In vitro digestion assay at $2 \mathrm{~h}$. Percent of the original assayed aliquot that remains intact is compared in different substrates. (A) Shows percent of the original assayed aliquot that remains intact of ${ }^{125} \mathrm{I}$-rhEpo as measured by TCA. $(B)$ Shows unlabeled rhEpo as measured by RIA. On the horizontal axis, the substrates are grouped into three digestion groups: gastric juices at preprandial $\mathrm{pH}$ (3.2) and postprandial $\mathrm{pH}$ (5.8) and intestinal juices at $\mathrm{pH}$ 7.4. The substrates used are rat milk (RM) (white bars), RMS (gray bars), and saline $(S)$ (black bars). Both TCA and RIA assays measured higher rhEpo levels in RM or RMS than in S (post hoc testing), * $p<0.05$. In both assays, rhEpo levels were higher in RM than RMS in the intestinal juices (post hoc testing), $\dagger p<0.05$.

or RMS than in saline alone when incubated in gastric (preand postprandial $\mathrm{pH}$ levels) and small intestinal juices $\left(F_{2,12}=\right.$ 54.0, $p<0.0001, F_{2,12}=18.8, p<0.001, F_{2,12}=13.9, p<$ 0.001 , respectively, with post hoc $p<0.05$ ). In small intestinal juices, rhEpo levels in rat milk were higher than in RMS (with post hoc $p<0.05$ ). TCA analysis overestimated measured immunoreactive Epo; however, degradation patterns seen with TCA analysis and RIA were similar.

The ability of rat milk to protect rhEpo from gastrointestinal proteolytic degradation was also evaluated in vivo at 1,2 , and $4 \mathrm{~h}$ after feeding. Except where noted, data shown represent the findings of the 2-h postfeed point because peripheral distribution of ${ }^{125} \mathrm{I}$-rhEpo was observed to peak in most tissues at this time. We found that ${ }^{125} \mathrm{I}$-rhEpo from stomach wall and lumen migrated at the same molecular weight as unfed intact ${ }^{125} \mathrm{I}$ rhEpo, $36.5 \mathrm{kD}$, on a $15 \%$ SDS-PAGE gel (Fig. 2). Because the TCA method approximates intact Epo both in vitro and in vivo, we used it to show that enteral ${ }^{125}$ I-rhEpo is better protected from gastrointestinal proteolytic degradation when adminis- 


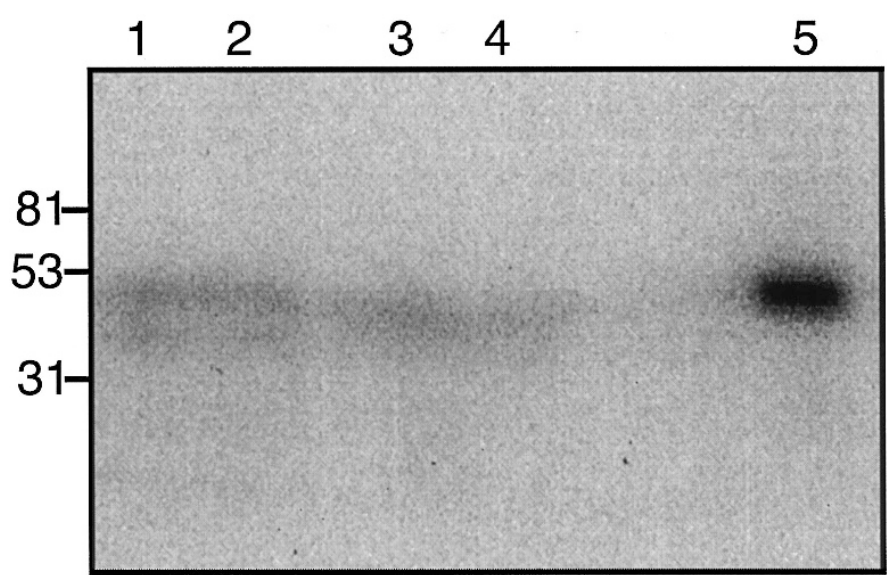

Figure 2. Autoradiography of SDS-PAGE showing the mobility of rhEpo from gastric tissues. Stomach wall (lanes 1,3) and stomach flush (lanes 2, 4) from two different animals show radiolabeled rhEpo mobility equivalent to intact rhEpo from the feed (36.5 kD, lane 5).

tered in rat milk versus saline in $0.25 \%$ BSA (gastric, jejunal and ileal lumens, and jejunal and ileal walls, $p<0.05$ ) (Fig. 3).

Intact rhEpo is distributed locally to gastrointestinal tissues and peripherally to distant tissues. Distribution of total and acid-precipitable counts as percent total ${ }^{125}$ I-rhEpo dose administered in the gastrointestinal tissues, corresponding lumens, and distant sites $2 \mathrm{~h}$ after enteral administration is shown in Figure 4. Because gastrointestinal lumen contains digestive juices and gastrointestinal wall possesses EpoR, we transformed the data from stomach, duodenum, jejunum, and midjejunum in Figure 4 to show the ratio of acid-precipitable (intact) counts over total counts (Fig. 5) in lumen and wall. In stomach, duodenum, and midjejunum, relatively more Epo

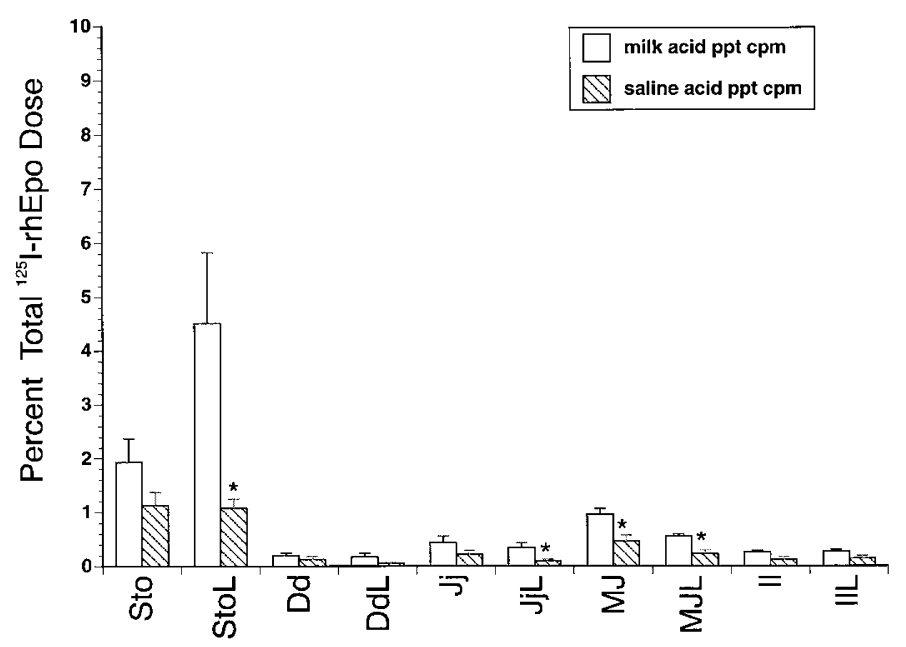

Figure 3. Evaluation of intact rhEpo $2 \mathrm{~h}$ after enteral administration to rat pups in milk $v s$ saline. Intact acid-precipitable counts (in percent total ${ }^{125} \mathrm{I}-$ rhEpo dose administered) are listed on the vertical axis, and gastrointestinal tissue or luminal flushes are listed on the horizontal axis. Tissues shown on the horizontal axis are stomach $(S t o)$ and lumen $(S t o L)$, duodenum $(D d)$ and lumen $(D d L)$, jejunum $(J j)$ and lumen $(J j L)$, midjejunum $(M J)$ and lumen $(M J L)$, and ileum $(I l)$ and lumen $(I L L)$. The white bars indicate ${ }^{125} \mathrm{I}$-rhEpo administered in banked RM, and cross-hatched bars indicate ${ }^{125} \mathrm{I}$-rhEpo administered in saline, ${ }^{*} p<0.05$. Data represent 16 rats from three different experiments.

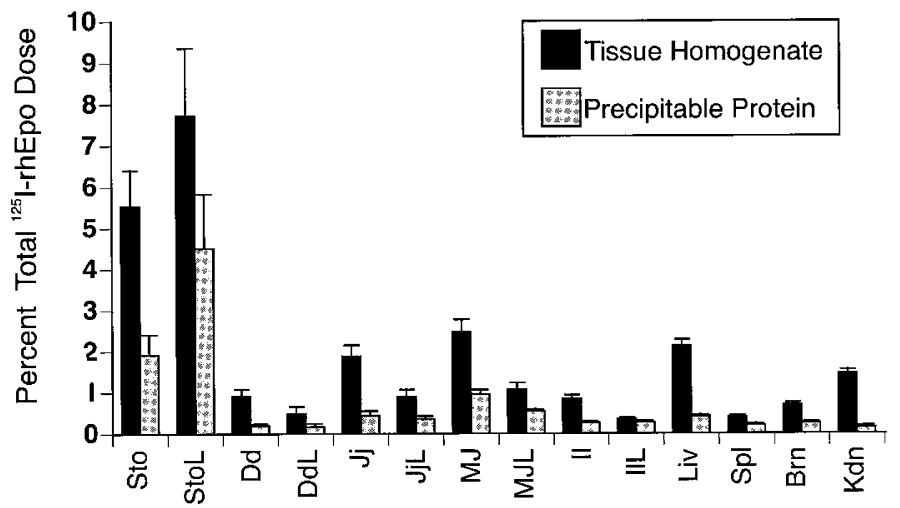

Figure 4. Distribution of total and intact label $2 \mathrm{~h}$ after enteral administration of ${ }^{125}$ I-rhEpo. Total counts (black bars) and acid-precipitable protein (gray bars) in percent of total ${ }^{125} \mathrm{I}$-rhEpo dose administered are listed on the vertical axis. Tissues shown on the horizontal axis are the same as in Figure 3, plus liver $(L i v)$, spleen $(S p l)$, brain $(B r n)$, and kidney $(K d n)$.

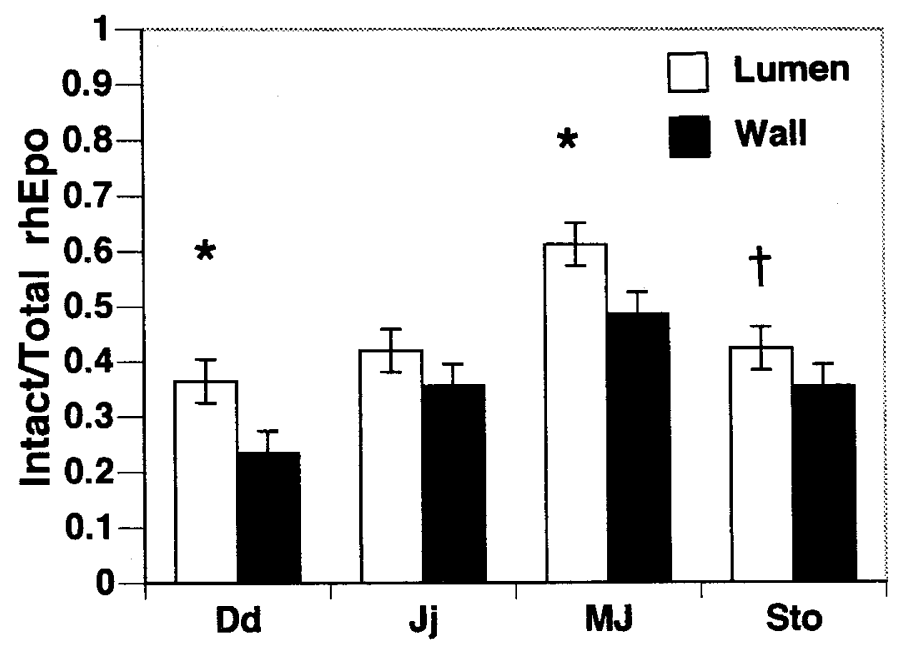

Figure 5. Ratio of intact/total counts from the gastrointestinal tissue wall and lumen $2 \mathrm{~h}$ after enteral administration of ${ }^{125} \mathrm{I}-\mathrm{rhEpo}$. The ratios of TCAprecipitable (intact) over total counts are shown on the vertical axis, with tissues listed on the horizontal axis. Lumen is shown in white and tissue wall in black. The ratios of wall vs lumen are compared, ${ }^{*} p<0.005, \uparrow p<0.05$.

located in the wall has undergone degradation compared with Epo located in corresponding lumen.

Epo as an endocrine hormone is delivered to the bone marrow via the circulation. Figure 6 shows that at 1, 2, and $4 \mathrm{~h}$ after enteral administration, $5 \%$ of the total ${ }^{125} \mathrm{I}$-rhEpo dose is found intact in the plasma fraction of blood. This percentage is comparable to percentages of s.c. dosed rhEpo seen in plasma by ourselves and others $(27,28)$. Eight, 9 , and $10 \%$ of the total enterally administered dose reached bone marrow at 1,2 , and $4 \mathrm{~h}$, respectively (Fig. 6). Representative marrow biopsies showed that $2.7 \%$ of total administered dose was intact in bone marrow between $1-4 \mathrm{~h}$ after feeding (data not shown). During infancy, all bone marrow is hematopoietic (29), so we compared bone marrow distribution of counts after enteral and parenteral (s.c.) administration. At $2 \mathrm{~h}$, the percentage of administered total counts reaching the bone marrow is similar whether dosed enterally $(9 \%)$ or parenterally $(8 \%)$. In a subset of rats dosed enterally $(n=2)$ or parenterally s.c. in the posterior neck near the foreleg $(n=2)$ and killed at $2 \mathrm{~h}$ after 


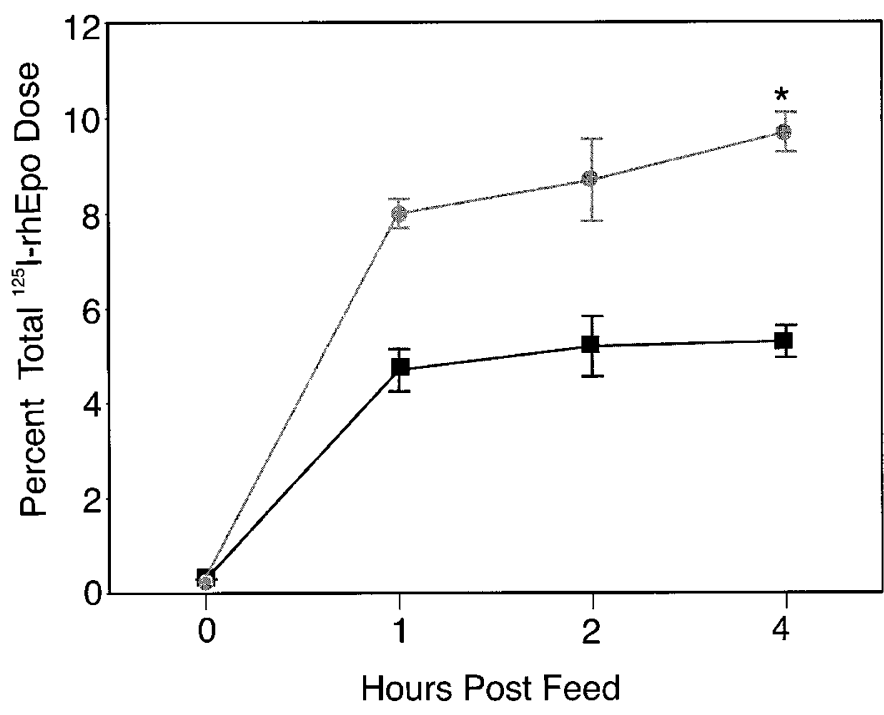

Figure 6. Plasma and bone marrow distribution over time. Percent of total ${ }^{125} \mathrm{I}$-rhEpo dose administered is shown on the vertical axis, and baseline (0), 1 , 2 , and 4-h intervals are shown on the horizontal axis. Intact plasma counts (black boxes) at 1, 2, and 4-h values are similar. Total bone marrow counts (gray circles) rise over time, with the percent at $4 \mathrm{~h}$ greater than at $1 \mathrm{~h},{ }^{*} p<$ 0.03 .

dose, bones were dislocated at predetermined joints, counted, and counts were correlated with bone weight (Fig. 7). This correlation was stronger after enteral administration $\left(R^{2}=\right.$ $0.80, p<0.0001)$ than after s.c. administration $\left(R^{2}=0.493, p\right.$ $<0.02$ ), supporting a more even distribution of rhEpo to hematopoietic tissues after enteral administration.

\section{DISCUSSION}

Similar to our previous work with human milk (5), the presence of rat milk or RMS formula protects rhEpo from degradation by rat gastric and small intestinal juices in the in

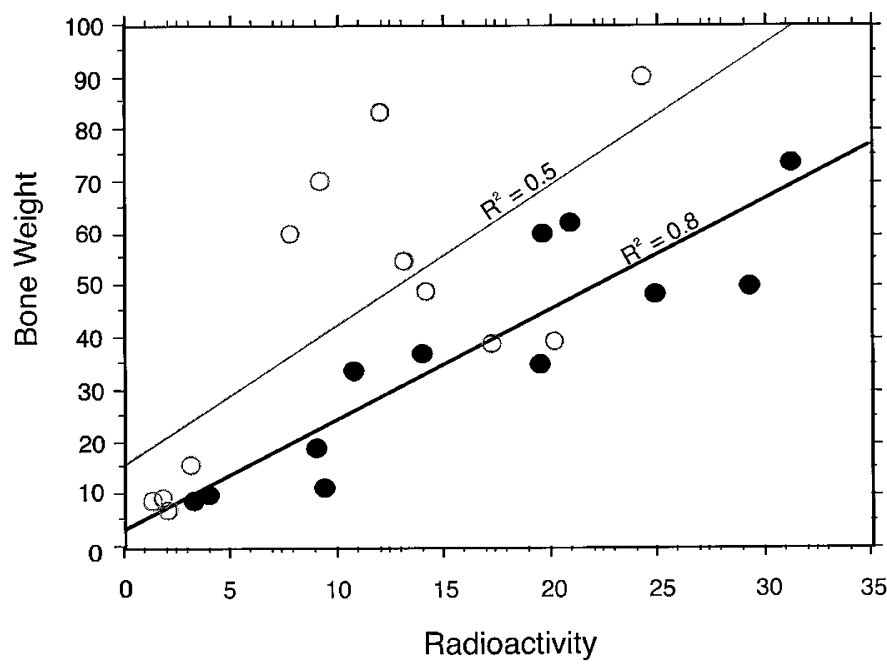

Figure 7. Relative amount of ${ }^{125} \mathrm{I}$-rhEpo delivered to bone by enteral vs s.c. (parenteral) administration after $2 \mathrm{~h}$. Regressions of bone weight (grams) on vertical axis compared with radioactivity $(\mathrm{cpm} \times 1000)$ on horizontal axis ( closed circles $=$ enteral, open circles $=$ parenteral). The correlation between weight and radioactivity for enteral $\left(R^{2}=0.8, p<0.0001\right)$ was stronger than for parenteral $\left(R^{2}=0.5, p<0.02\right)$ dosing vitro digestion assay as measured by TCA precipitation or RIA. When comparing the in vitro studies of rhEpo in rat milk, relative amounts of intact rhEpo measured by TCA precipitation and RIA are remarkably similar (85 to $98 \%$ of initial dose found as intact). However, the TCA and RIA methods were more discrepant in comparing rhEpo in RMS or saline. Percentage of intact rhEpo when in RMS appears higher with TCA (65 to $85 \%$ ) compared with RIA ( 25 to $65 \%$ ). Additionally, when rhEpo was in saline, the TCA method showed a much higher percentage of intact rhEpo (35 to 75\%) compared with RIA (5 to $25 \%$ ). TCA studies may overestimate intact proteins such as Epo. Widness et al. (27) found that TCA precipitation overestimates rhEpo by 10 to $30 \%$ after parenteral rhEpo administration when compared with immunoprecipitation, immunoassay, or bioassay techniques, presumably as TCA precipitates the larger degradative products of rhEpo. An additional explanation of the findings in RMS and saline is that these vehicles lack specific protease inhibitors contained in rat milk (8) and gastrointestinal juices degraded rhEpo samples during the $24 \mathrm{~h}$ at room temperature while the RIA was being performed compared with the TCA precipitation method that took only minutes to perform.

We selected acid precipitation as a first step in these in vitro and in the in vivo degradation studies, secondary to its ease of use in localizing and determining the fate of other enteral growth factors in previous studies $(7,30,31)$. Our initial disposition studies show that when rhEpo is present in rat milk, TCA results correlated very highly with RIA, and in vivo studies identify intact rhEpo in local gastrointestinal tissues, systemic circulation, and distant tissues. However, the abovereported TCA method is of insufficient specificity for precise pharmacokinetic plasma studies (27), and additional studies with a more specific method such as immunoprecipitation are necessary to analyze whether escalating pharmacologic doses result in higher levels in plasma and bone marrow.

Proteins such as rhEpo are spared from gastrointestinal degradation because the neonatal gastrointestinal tract exhibits relatively less proteolytic activity and more mucosal permeability to intact proteins than later in life $(6,8)$. Milk itself further protects proteins from degradation by raising gastric $\mathrm{pH}$, which limits conversion of proteolytic enzymes to their active forms and by providing specific inhibitors of proteolytic enzymes (8). It is likely that cow's milk-based artificial formulas are less effective in protecting proteins from degradation. A previous study in suckling rats suggested that erythropoietic effects of enteral rhEpo administration are greatest in the presence of milk (11). Two human studies observed that plasma Epo levels in premature infants rose after enteral rhEpo administration $(13,14)$, but measurable changes in erythropoiesis occurred only after rhEpo was administered in infant formula (14). We have confirmed these findings with our suckling rat studies. We have shown with this work that enterally administered rhEpo resists proteolytic degradation, especially in the presence of rat milk, and that milk-borne rhEpo is distributed throughout the gut, to hematopoietic tissues, and to other peripheral organs.

Previous published studies of enteral Epo in suckling animals $(10-12,32)$ and premature human infants $(13,14)$ report 
only the erythropoietic effects of Epo. However, EpoR have been identified in gastrointestinal cells, and in vitro studies support physiologic roles of rhEpo in these cells $(3,4)$. Before birth, the fetus swallows amniotic fluid rich in trophic and protective growth factors needed for gastrointestinal development $(8,33,34)$. Epo, one of these growth factors, is present at high levels in amniotic fluid and at higher levels during fetal hypoxia $(35,36)$.

We found biologically relevant amounts of intact rhEpo distributed to the local gastrointestinal tract, the plasma, and peripheral organs after enteral rhEpo administration. Relatively greater degradation is observed within the wall of the stomach and small intestine compared with the lumen. As wall possesses EpoR, these data support a potential role for tissue receptor-mediated endocytosis rather than luminal proteolytic degradation. Epo is degraded rapidly by lysosomes after ligand-occupied EpoR are internalized by endocytosis $(23,37$, 38 ). With physiologic doses of rhEpo such as ours, this pathway of degradation is rapid but slows as doses increase and receptors are saturated $(37,39)$. This phenomenon needs further study with higher enteral doses of rhEpo and more specific assay methods.

At 1, 2, and $4 \mathrm{~h}$ after feeding, plasma Epo levels remained steady at $5 \%$ of the total dose given, which suggests a steady supply of intact rhEpo. Subcutaneously administered rhEpo in humans results in a similar pattern with relatively low steady plasma levels $(40,41)$ and is generally considered to be more efficacious than i.v. bolus (42). Continuous i.v. infusion also results in steadier plasma concentrations and appears to be more efficacious than i.v. bolus (43). The finding that 5 and $2.7 \%$ of our administered dose was intact in plasma and bone marrow, respectively, is similar to the percentages seen in rats administered i.v. bolus Epo (28). It is important to note, however, that the plasma Epo levels we report here remained steady at $5 \%$ of the dose for at least $4 \mathrm{~h}$, unlike the rapid peak and fall seen with i.v.-administered Epo $(44,45)$. The percentage of total dose reaching bone marrow was similar whether dosed enterally or s.c., but enteral dosing resulted in a more even distribution per gram of bone. As nearly all marrow is hematopoietic in neonates (29) and EpoR in marrow may saturate with relatively low $(1.25 \mathrm{U} / \mathrm{kg})$ rhEpo i.v. bolus doses (43), the low-level steady delivery of rhEpo enteral administration may offer an advantage over i.v. bolus in the clinical setting.

In summary, we observed that milk protects rhEpo from proteolytic degradation and that enterally administered radiolabeled rhEpo is distributed locally in the gastrointestinal tract and peripherally to the plasma, bone marrow, and other distal organs. Our current results are the first in vivo data to show that rhEpo is distributed in a pattern suggesting both local gastrointestinal cellular processing and systemic absorption. These findings warrant continued investigation into the fate, pharmacokinetics, tissue receptor binding, and biologic roles of enterally administered rhEpo.

Acknowledgments. The authors thank Robin Roberts, Deborah McWilliams, Gregory Hadden, Travis Higdon, Carrie
Daniel, Julie Shelton, and Jessica Dominguez for their technical assistance.

\section{REFERENCES}

1. McCuskey RS, Meineke HA 1977 Studies of the hemopoietic microenvironment. V. Erythropoietin-induced release of vasoactive substance(s) from erythropoietinresponsive stem cells. Proc Soc Exp Biol Med 156:181-185

2. Carlini RG, Reyes AA, Rothstein M 1995 Recombinant human erythropoietin stimulates angiogenesis in vitro. Kidney Int 47:740-745

3. Okada A, Kinoshita Y, Maekawa T, Hannan MS, Kawanami C, Asahara M, Matsushima M, Kishi K, Nakata H, Naribayashi Y, Chiba T 1996 Erythropoietin stimulates proliferation of rat-cultured gastric mucosal cells. Digestion 57:328-332

4. Juul SE, Joyce AE, Zhao Y, Ledbetter DJ 1999 Why is erythropoietin present in human milk? Studies of erythropoietin receptors on enterocytes of human and rat neonates. Pediatr Res 46:263-268

5. Kling PJ, Sullivan TM, Roberts RA, Philipps AF, Koldovsky O 1998 Human milk as a potential enteral source of erythropoietin. Pediatr Res 43:216-221

6. Thornburg W, Rao RK, Matrisian LM, Magun BE, Koldovsky O 1987 Effect of maturation on gastrointestinal absorption of epidermal growth factor in rats. Am J Physiol 253:G68-G71

7. Philipps AF, Rao RK, Anderson GG, McCracken DM, Lake M, Koldovsky O 1995 Fate of insulin-like growth factors I and II administered orogastrically to suckling rats. Pediatr Res 37:586-592

8. Koldovsky O 1996 The potential physiological significance of milk-borne hormonally active substances for the neonate. J Mamm Gland Biol Neoplasia 1:317-322

9. Mizuno A, Ueda M, Kawanishi G 1991 Effects of salicylate and other enhancers on rectal absorption of erythropoietin in rats. J Pharm Pharmacol 44:570-573

10. Carmichael RD, Gordon AS, LoBue J 1978 Erythropoietic response of hypertransfused neonatal rats suckled by anemic mothers. Anat Rec 191:227-238

11. Carmichael RD, Gordon AS, LoBue J 1978 The effects of maternal phlebotomy and orally-administered erythropoietin (Ep) on erythropoiesis in the suckling rat. Biol Neonate 33:119-131

12. Carmichael RD, LoBue J, Gordon AS 1992 Neonatal erythropoiesis. I. Peripheral blood erythropoietic parameters: data suggest erythropoietin transfer via maternal milk. Endocr Regul 26:83-88

13. Britton JR, Christensen RD 1995 Enteral administration of recombinant erythropoietin to preterm infants. J Perinatol 15:281-283

14. Ballin A, Bilker-Reich A, Arbel E, Davidovitz Y, Kohelet D 1999 Erythropoietin, given enterally, stimulates erythropoiesis in premature infants. Lancet 353:1849

15. Ledbetter DJ, Juul SE 2000 Erythropoietin and the incidence of necrotizing enterocolitis in infants with very low birth weight. J Pediatr Surg 35:178-182

16. Kurtz A, Matter R, Eckardt KU, Zapf J 1990 Erythropoiesis, serum erythropoietin, and serum IGF-I in rats during accelerated growth. Acta Endocrinol 122:323-328

17. Koldovsky O 1989 Hormones in milk: their possible physiological significance for the neonate. In: Lebenthal E (ed) Textbook of Gastroenterology and Nutrition in Infancy. Raven Press, New York, pp 97-119

18. Wen D, Boissel JPR, Gruninger RH, Mulcahy LS, Czelusniak J, Goodman M, Bunn HF 1993 Erythropoietin structure-function relationships: high degree of sequence homology among mammals. Blood 82:1507-1516

19. Schaudies RP, Grimes J, Wray HL, Koldovsky O 1990 Identification and partial characterization of multiple forms of biologically active EGF in rat milk. Am J Physiol 22:G1056-G1061

20. Dvorak B, Stepankova R 1992 Effects of dietary essential fatty acid deficiency on the development of rat thymus and immune system. Prostaglandins Leukot Essent Fatty Acids 46:183-190

21. Britton JR, George-Nascimento C, Koldovsky O 1988 Luminal hydrolysis of recombinant human epidermal growth factor in the rat gastrointestinal tract: segmental and developmental differences. Life Sci 43:1339-1347

22. Lebenthal E, Siegel M 1985 Understanding gastric emptying: implications for feeding the healthy and compromised infant. J Pediatr Gastroenterol Nutr 4:1-3

23. Sawyer ST, Krantz SB, Goldwasser G 1987 Binding and receptor-mediated endocytosis of erythropoietin in Friend virus-infected erythroid cells. J Biol Chem 262:5554-5562

24. Britton JR, Koldovsky O 1989 Transferrin degradation by gastrointestinal fluids of suckling and weanling rats. J Dev Physiol 11:57-61

25. Yahav J, Carrion V, Lee PC, Lebenthal E 1987 Meal-stimulated pepsinogen secretion in premature infants. J Pediatr 110:949-951

26. Rao RK, Koldovsky O, Grimes J, Williams C, Davis TP 1991 Regional differences in gastrointestinal processing and absorption of epidermal growth factor in suckling rats. Am J Physiol 261:G790-G798

27. Widness JA, Schmidt RL, Modi N, Veng-Pedersen P, Sawyer ST 1992 A sensitive and specific erythropoietin immunoprecipitation assay: application to pharmacokinetic studies. J Lab Clin Med 119:285-294

28. Emmanouel DS, Goldwasser E, Katz AI 1984 Metabolism of pure human erythropoietin in the rat. Am J Physiol 274:F168-F176

29. Hann IM 1991 Development of blood in the fetus. In: Hann IM, Gibson BES, Letsky EA (eds) Fetal and Neonatal Haematology. Bailliere Tindall, London, pp 1-28

30. Thornburg W, Matrisian L, Magun B, Koldovsky O 1984 Gastrointestinal absorption of epidermal growth factor in suckling rats. Am J Physiol 246:G80-G85

31. Koldovsky O 1989 Search for role of milk-borne biologically active peptides for the suckling. J Nutr 119:1543-1551

32. Grant W 1952 Influence of anoxia of a lactating rat on the blood of normal baby rats Am J Physiol 171:728-729(abstr) 
33. Trahair JF, Wing SJ, Quinn KJ, Owens PC 1997 Regulation of gastrointestinal growth in fetal sheep by luminally administered insulin-like growth factor-I. J Endocrino 152:29-38

34. Kelly EJ, Newell SJ, Brownlee KG, Farmery SM, Cullinane C, Reid WA, Jackson P, Gray SF, Primrose JN, Lagopoulos M 1997 Role of epidermal growth factor an transforming growth factor alpha in the developing stomach. Arch Dis Child 76:F158-F162

35. Teramo KA, Widness JA, Clemons GK, Voutilainen P, McKinlay S, Schwartz R 1987 Amniotic fluid erythropoietin correlates with umbilical plasma erythropoietin in normal and abnormal pregnancy. Obstet Gynecol 69:710-716

36. Voutilainen P, Widness JA, Clemons GK, Schwartz R, Teramo K 1989 Amniotic fluid erythropoietin predicts fetal distress in Rh-immunized pregnancies. Am J Obstet Gynecol 160:429-434

37. Kinoshita H, Ohishi N, Kato M, Okazaki A 1992 Pharmacokinetics and distribution of recombinant erythropoietin in rats. Prog Drug Res 42:174-178

38. Neumann D, Wikstrom L, Watowich SS, Lodish HF 1993 Intermediates in degradation of the erythropoietin receptor accumulate and are degraded in lysosomes. J Biol Chem 268:13639-13649
39. Mufson RA, Gesner TG 1987 Binding and internalization of recombinant human erythropoietin in murine erythroid precursor cells. Blood 69:1485-1490

40. Brown MS, Jones MA, Ohls RK, Christensen RD 1993 Single-dose pharmacokinetics of recombinant human erythropoietin in preterm infants after intravenous and subcutaneous administration. J Pediatr 122:655-657

41. Krishnan R, Shankaran S, Krishnan M, Kauffman R, Kumar P, Lucena J 1996 Pharmacokinetics of erythropoietin following single-dose subcutaneous administration in preterm infants. Biol Neonate 70:135-140

42. Eschbach JW, Kelly MR, Haley NR, Abels RI, Adamson JW 1989 Treatment of the anemia of progressive renal failure with recombinant human erythropoietin. N Eng J Med 321:158-163

43. Ohls RK, Veerman MW, Christensen RD 1996 Pharmacokinetics and effectiveness of recombinant erythropoietin administered to preterm infants by continuous infusion in total parenteral nutrition solution. J Pediatr 128:518-523

44. Veng-Pedersen P, Hong SS, Widness JA, Schmidt RL 1998 Correction for non-ideal tracer pharmacokinetic disposition analysis (DDA). Pharmacol Res 15:1469-1473

45. Spivak JL, Hogans BB 1989 The in vivo metabolism of recombinant human erythropoietin in the rat. Blood 73:90-99 